\title{
Report from the Mid-Atlantic Region
}

\section{Sean Wilentz}

\section{Princeton University}

On November 6 and 7, 1980, the Institute for Research in History sponsored an international conference in New York City on the origins of Anglo-American radicalism. It was an exhausting affair, that included sessions on a dozen precirculated papers, keynote lectures and commentaries, and considerable discussion and debate from the floor. Among the highlights were Christopher Hill's paper, linking (if only speculatively) Daniel Defoe, piracy, English radicalism, and changing relations of labor in the seventeenth-century Carribean; Alfred Young's paper on eighteenth-century American popular culture and radicalism (with a commentary by Pauline Maier); and two especially lively sessions on recent trends in the historiography of the English Civil War and on liberal capitalism, popular movements, and ideology in America from the Revolution through the age of Jefferson. The organizers, John and Margaret Jacob, along with the Institute are to be congratulated for having brought together so many scholars whose interests intersect. It is hoped with publication of the papers in book form expected in the near future, they will reach the wider audience they deserve.

Also on the international front, the Milan Group on the History of the Early United States has announced its formation and is eager to hear from any Americans working on social and labor history from the colonial period through the early nineteenth century. The Group, begun as an informal network of scholars who attended an earlier conference in Milan on American radicalism, consists of a few Americans and several Americanists from Australia, France, Germany, Italy, and the United Kingdom. It aims to deepen the heretofore tentative contacts between historians outside of this country and resident historians, to exchange news and notes and otherwise help make the study of early America more of an international enterprise. A conference on republicanism and American society, from the Revolution to 1840 , has been scheduled for next June; plans are underway to publish a regular news bulletin. Anyone interested in joining the group should send his or her name and address and a brief summary of past research and future projects to Loretta Valtz Manucci, v. Cappucio 3, Milan, Italy. 
The Columbia University Seminar on the History of the Working Class has announced its schedule for 1981-1982; those interested should contact either Helmut Gruber, 425 Riverside Drive, New York, NY 10027 or Carol Groneman, Department of History, John Jay College of Criminal Justice, 445 West 59th Street, New York, NY 10019.

The Eleutherian Mills-Hagley Foundation in Wilmington will sponser an allday conference, entitled Industrious Women, on women's work in early America, on September 26. Also in Wilmington, the Delaware Art Museum is running both an exhibition and a lecture series on Work, Leisure, and the Academic Tradition: Reflections on Changing Attitudes, in October and November; for information write the museum at 2301 Kentmere Parkway, Wilmington, DE 19806.

With the death of Henry J. Browne earlier this year, we lost an erudite historian of sympathetic imagination and a community activist of extraordinary commitment. The City of New York has honored his memory by renaming a portion of West 90th Street (location of his parish, St. Gregory's) Harry J. Browne Boulevard; the Great Falls Foundation in Passaic has renamed its lecture series in his name. For information on the series, write the Foundation. 